DOI: $10.19195 / 2658-1310.25 .4 .3$

Dawid Banaś

ORCID: 0000-0002-8568-3861

Uniwersytet Ekonomiczny w Poznaniu

dawid.banas@ue.poznan.pl

\title{
Adekwatność konsumpcyjna systemów emerytalnych w państwach postradzieckich w latach 2005-2017
}

Artykuł nadesłany: 21.01.2019; artykuł zaakceptowany: 12.09.2019

Kody klasyfikacji JEL: H55, H75

Keywords: consumption adequacy, post-Soviet countries, pension systems

\section{Abstract}

Consumption adequacy of pension systems in post-Soviet countries in 2005-2017

Adequacy, together with stability and modernization, are the goals which are set for pension systems by many researchers from various scientific disciplines. This is because more and more countries struggle with the problem of providing adequate financing for social transfers, including pensions. This means that despite paying contributions for a significant part of life, many citizens receive a low pension at the end of their working lives. Therefore, it is important to maintain the standard of living from earlier years. Consumption adequacy is responsible for this, which helps to smooth the consumption in the last period of the individual's life. This aspect is also important due to the decline in the value of benefit during its collection despite valorization and, at the same time, the growth of some needs along with the retiree's age (including care services).

The aim of this article is to organize particular pension systems in post-Soviet countries in terms of consumption adequacy (from the most adequate system to the least) understood as smoothing consumption. In the next step, there will be an attempt to evaluate the indicator. This work employs a critical analysis of the literature on the subject, as well as a comparative analysis. The source of the empirical data is the statistical offices of the individual states, which were created after the collapse of the Union of Soviet Socialist Republics (USSR).

The research shows that the Baltic States have one of the most adequate pension systems from the studied group of countries. Only five of them meet the requirements of the International Labor Organization. None of the analyzed countries in 2017 had a replacement rate above $50 \%$. 


\section{Wstęp}

Celem artykułu jest próba oceny adekwatności konsumpcyjnej w państwach postradzieckich, które powstały po upadku ZSRR. Są to: Armenia, Azerbejdżan, Białoruś, Estonia, Gruzja, Kirgistan, Kazachstan, Litwa, Łotwa, Mołdawia, Rosja, Tadżykistan, Ukraina i Uzbekistan. Z powodu niedostępności danych $\mathrm{w}$ analizie został pominięty Turkmenistan.

Autor zdecydował się na tę grupę krajów, gdyż są to państwa, które przez ponad pół wieku miały wspólną gospodarkę ${ }^{1}$. Od prawie 30 lat są one samodzielnymi podmiotami. Oznacza to, że niedługo z rynku pracy będą odchodzić kohorty osób, które rozpoczynały aktywność zawodową w okresie transformacji ustrojowo-gospodarczej. Dodatkowym powodem zainteresowania się tym obszarem geograficznym jest fakt, że państwa te nie są uwzględniane w międzynarodowych raportach, na przykład w opublikowanym przez OECD opracowaniu pod tytułem Pensions at a Glance 2017: OECD and G20 Indicators, w którym z byłych państw ZSRR uwzględniane są tylko: Estonia, Łotwa i Rosja. W związku z tym warto sprawdzić, czy emerytura, którą niedługo będą mogli zacząć pobierać obywatele tych państw, a także pozostałych krajów postradzieckich, pozwoli na utrzymanie konsumpcji na poziomie zbliżonym do obecnego.

Celem niniejszego opracowania jest weryfikacja hipotezy: ,państwa znajdujące się na terytorium Europy mają wyższą adekwatność konsumpcyjną niż państwa znajdujące się w Azji”".

\section{Przyczyny badań nad adekwatnością systemów emerytalnych}

Na dłuższe życie ludzi na prawie całym świecie ma wpływ wiele czynników. Spośród nich niewątpliwie należy wskazać postęp technologiczny oraz szeroko pojmowane zmiany w stylu życia. Zjawisko wydłużania się życia ludzkiego jest niepodważalnym sukcesem, z którego powinniśmy się cieszyć. Sukces w skali mikro skutkuje jednakże dużymi problemami w skali makro, albowiem dochodzi również do starzenia się demograficznego. A. Pleśniak $(2014,44)$ stwierdza, że przyczyniają się do niego, oprócz wspomnianego dłuższego życia, chociażby migracje czy spadek współczynnika dzietności. Skutkiem tych zmian jest sytuacja, w której coraz większa liczba państw na świecie musi borykać się z problemami niewypłacalności swoich systemów emerytalnych. Spowodowane jest to tym, że osoby starsze coraz dłużej przebywają na emeryturze, co oznacza, że przez cały czas pobierają transfery socjalne. Bardzo często nie mają one obaw o to, czy już skonsumowały wszystkie składki, jakie odłożyły w okresie swojej aktywności za-

1 ZSRR istniał w latach 1922-1991 (Związek Socjalistycznych Republik Radzieckich, 2018). 
wodowej. Jednocześnie ludzie młodzi opóźniają moment wejścia na rynek pracy, głównie z powodu dłuższego podnoszenia swojego wykształcenia.

T. Maleva i O. Sinâvskaâ w swoich badaniach wskazują na przykładzie Rosji, jak zmniejszył się czas przebywania na rynku pracy. Wykazują, że w 1932 roku Rosjanie rozpoczynali aktywność zawodową w wieku 14-16 lat i przebywali na rynku pracy do 60. roku życia, kiedy to przechodzili na emeryturę zgodnie z uwarunkowaniami prawnymi. Okres aktywności zawodowej w tamtym czasie wynosił około 45 lat. Obecnie wejście na rynek pracy przesunęło się do momentu, w którym statystyczny Rosjanin jest w wieku 20-22 lat. W kraju tym bardzo często są także na dużą skalę wykorzystywane możliwości wcześniejszego przejścia na emeryturę, na które pozwala tamtejszy system emerytalny ${ }^{2}$. Skutkuje to tym, że okres aktywności zawodowej kończy się po około 32-34 latach pracy (przy założeniu, że nie występują długie przerwy między różnymi momentami zatrudnienia). Widać więc, że okres aktywności zawodowej mężczyzn zmniejszył się o około 11-13 lat; w wypadku kobiet czas ten wynosi średnio 10 lat (Maleva, Sinâvskaâ, 2011, 13).

Taka sytuacja powoduje, iż znacznie zmniejsza się wysokość środków zgromadzonych na kontach i subkontach poszczególnych jednostek (odłożonych składek), które później zostaną wykorzystane na transfery socjalne w okresie starości. W przyszłości poskutkuje to tym, że wypłacane świadczenia będą stosunkowo niskie. W związku z tym powstaje pytanie, czy otrzymywane środki będą wystarczające na pokrycie potrzeb życiowych. Należy mieć na uwadze, że mimo braku przymusu oszczędzania na dalsze lata życia wydatki osób starszych wraz z wiekiem mogą rosnąć, zwłaszcza z powodu potrzeb związanych z usługami opiekuńczymi i medycznymi. Wydatki te mogą wynikać z nieotrzymywania pomocy ze strony rodziny lub wymogu używania specjalistycznego sprzętu.

Na problem starzenia się zwraca uwagę również T. Szumlicz, który wyróżnia dwie fazy ryzyka związanego ze starością. Pierwsza z nich dotyczy dożycia wieku emerytalnego i spokojnego życia po zaprzestaniu aktywności zawodowej (Szumlicz, 2006, 221). Druga faza natomiast wiąże się z problemem ,zbyt długiego życia" 3 - oznacza ona brak środków potrzebnych do egzystencji z powodu wcześniejszego wykorzystania wszystkich zaoszczędzonych w trakcie życia aktywów finansowych (Szumlicz, 2004, 11). Aby zabezpieczyć swoich obywateli przed życiem bez pieniędzy, rządy oferują świadczenia w formie annuitów, czyli dożywotnich wypłat transferów socjalnych (Góra, 2003, 17). Często ich zadaniem jest utrzymanie poziomu życia osób starszych powyżej linii ubóstwa.

W celu ukazania, iż ryzyko dożycia wieku emerytalnego realizuje się coraz częściej, a zmiany demograficzne nie dotyczą tylko państw wysoko rozwiniętych,

2 Uprawnienia do wcześniejszego przejścia na emeryturę mają między innymi osoby pracujące w zawodach o podwyższonym ryzyku oraz mieszkańcy dalekiej północy.

3 Punktem krytycznym jest przeciętny czas życia danej jednostki. 
w tabeli 1 przedstawiono odsetek osób w wieku 65 lat i więcej ${ }^{4}$ w państwach powstałych po upadku ZSRR, w latach 1960-2017. Należy jednak pamiętać, że każde państwo indywidualnie ustala wiek emerytalny ${ }^{5}$, w związku z czym odsetek osób starszych, rozumianych w tym artykule jako osoby $65+$ (niezależnie od płci), jest niższy niż odsetek osób dożywających wieku emerytalnego.

Najwięcej osób starszych (to jest powyżej 65 lat) w grupie analizowanych państw żyje w krajach bałtyckich: w Litwie, Łotwie i Estonii — odsetek osób starszych w tych krajach wynosił 19\% i więcej. Na początku analizowanego okresu wskaźnik ten był najwyższy w wypadku Łotwy i Estonii i wynosił prawie 11\%, natomiast na Litwie było to niecałe $8 \%$. Wyższe wskaźniki odnotowywały jedynie Białoruś i Gruzja. Z kolei najniższy współczynnik obciążenia ludźmi starszymi w 1960 roku był w Tadżykistanie i Turkmenistanie (około 5\%).

Warto zwrócić uwagę, że od lat osiemdziesiątych XX wieku państwa postradzieckie można podzielić na dwie podgrupy, które zdecydowanie różnią się odsetkiem osób starszych w społeczeństwie.

Pierwsza z nich charakteryzuje się wskaźnikiem obciążenia ludźmi starszymi powyżej 7\% na początku lat osiemdziesiątych XX wieku i jego dalszym wzrostem aż do końca okresu badawczego (mimo okresowych załamań) do poziomu powyżej 11\%. Do grupy tej można zaliczyć: Mołdawię, Gruzję, Rosję, Białoruś, Ukrainę, a także Estonię, Litwę i Łotwę. Autor klasyfikuje do tej grupy także Armenię, która jeszcze do lat osiemdziesiątych XX wieku utrzymywała odsetek osób starszych na stałym poziomie - w okolicach 5\%. Natomiast już w latach dziewięćdziesiątych XX wieku państwo to odnotowało gwałtowny przyrost tego wskaźnika, który w 2006 roku wyniósł prawie 12\%.

Druga podgrupa to kraje, w których wskaźnik odnotował nieznaczny wzrost, to jest maksymalnie do 7\%, bądź nawet jego spadek. Można do niej zaliczyć: Kazachstan, Azerbejdżan, Kirgistan, Uzbekistan, Turkmenistan i Tadżykistan. Warto zwrócić szczególną uwagę na cztery ostatnie państwa, gdyż to właśnie w nich przez cały analizowany okres odnotowano spadek odsetka osób starszych w tamtejszych populacjach. Najniższa wartość tego wskaźnika w 2017 roku była w Tadżykistanie. Na początku okresu badawczego wynosił on mniej niż $5 \%$, natomiast na koniec spadł do $3 \%$.

${ }^{4}$ Autor nie zdecydował się na zaprezentowanie odsetka emerytów, gdyż w wielu państwach trwają obecnie reformy systemów emerytalnych. Mają one na celu podwyższenie minimalnego wieku umożliwiającego pobieranie świadczenia oraz zrównywanie prawnego wieku emerytalnego dla obu płci, na przykład w Estonii i na Łotwie ma on wynosić 65 lat zarówno dla kobiet, jak i mężczyzn — nastąpi to odpowiednio w 2026 i 2025 roku (European Commission, 2018). Istnieją także możliwości wcześniejszego przejścia na emeryturę, co mogłoby zniekształcać analizę.

${ }^{5}$ Przykładem reformy, w trakcie której podniesiono wiek emerytalny, jest reforma systemu emerytalnego w Rosji z 2018 roku. W wypadku mężczyzn ma on wzrosnąć z 60 do 65 lat, a dla kobiet ma to być wzrost z 55 do 60 lat (Federal'nyj zakon...). 
Tabela 1. Odsetek osób w wieku 65 lat i więcej w państwach postradzieckich w latach 19602017 (w \%)

\begin{tabular}{|l|r|r|r|r|r|r|r|r|r|r|}
\cline { 2 - 11 } \multicolumn{1}{c|}{} & 1960 & 1970 & 1980 & 1990 & 1995 & 2000 & 2005 & 2010 & 2015 & 2017 \\
\hline Armenia & 6,35 & 5,56 & 5,96 & 5,63 & 8,38 & 10,02 & 11,90 & 10,99 & 10,91 & 11,23 \\
\hline Azerbejdżan & 5,38 & 5,19 & 5,08 & 4,64 & 5,31 & 5,85 & 6,59 & 5,90 & 5,74 & 6,02 \\
\hline Białoruś & 8,37 & 9,04 & 10,77 & 10,69 & 12,45 & 13,50 & 14,74 & 13,99 & 14,34 & 14,80 \\
\hline Estonia & 10,55 & 11,79 & 12,51 & 11,66 & 13,60 & 15,02 & 16,76 & 17,52 & 18,82 & 19,45 \\
\hline Gruzja & 8,64 & 7,74 & 9,25 & 9,31 & 11,38 & 12,41 & 14,35 & 14,31 & 14,62 & 14,86 \\
\hline Kazachstan & 5,70 & 5,39 & 6,11 & 5,86 & 7,17 & 6,83 & 7,68 & 6,82 & 6,75 & 6,99 \\
\hline Kirgistan & 7,08 & 6,22 & 5,80 & 5,03 & 5,48 & 5,51 & 5,64 & 4,52 & 4,28 & 4,49 \\
\hline Litwa & 7,93 & 10,15 & 11,35 & 10,88 & 12,29 & 13,91 & 15,99 & 17,27 & 18,69 & 19,00 \\
\hline Lotwa & 10,57 & 12,02 & 13,07 & 11,88 & 13,72 & 14,99 & 16,86 & 18,18 & 19,28 & 19,75 \\
\hline Mołdawia & 6,18 & 6,33 & 7,74 & 8,29 & 9,01 & 9,42 & 9,93 & 10,15 & 9,94 & 10,86 \\
\hline Rosja & 6,09 & 7,72 & 10,29 & 10,31 & 12,13 & 12,44 & 13,82 & 13,09 & 13,49 & 14,18 \\
\hline Tadżykistan & 4,78 & 5,08 & 4,60 & 3,84 & 3,86 & 3,60 & 3,85 & 3,44 & 3,32 & 3,47 \\
\hline Turkmenistan & 5,20 & 4,65 & 4,25 & 3,77 & 4,10 & 4,28 & 4,59 & 4,14 & 4,07 & 4,28 \\
\hline Ukraina & 7,13 & 9,26 & 11,82 & 11,99 & 13,53 & 13,80 & 15,89 & 15,71 & 15,89 & 16,46 \\
\hline Uzbekistan & 5,91 & 5,92 & 5,16 & 4,11 & 4,45 & 4,62 & 4,84 & 4,51 & 4,23 & 4,47 \\
\hline
\end{tabular}

Źródło: World Bank (2018).

Do pogarszających się wskaźników demograficznych odniósł się pod koniec lat dziewięćdziesiątych XX wieku M. Okólski (1997). Stwierdził on, że większy stosunek osób starszych w populacji wymaga odpowiednich dostosowań, zarówno ekonomicznych, jak i społecznych. Wskazał również istotną rolę transferów rodzinnych oraz instytucjonalnych, a także potrzebę ich wzmocnienia. Jak jednak zauważa A. Pleśniak $(2014,48)$, w latach dziewięćdziesiątych XX wieku niemożliwe stało się utrzymanie hojnych systemów emerytalnych. Było to spowodowane zmianami demograficznymi. Wtedy też nastąpiło odchodzenie od istniejących w tamtym czasie systemów emerytalnych na rzecz adekwatnych.

Oprócz wskazanych problemów, takich jak wydłużanie się życia i opóźnienie momentu wejścia na rynek pracy, należy uwzględnić inne problemy demograficzne. Są to między innymi: starzenie się ludzi starszych oraz spadek wskaźnika dzietności, które przyczyniają się do zjawiska określanego mianem „odwrócenie piramidy wieku" (Jurek, 2012, 34). Nie powinno się także zapominać o migracjach zarobkowych, które są szczególnie widoczne na Ukrainie i w Mołdawii ${ }^{6}$.

${ }^{6}$ Najczęściej wyjeżdżają mężczyźni, którzy chcą zapewnić środki finansowe na utrzymanie rodziny, która pozostała w ojczyźnie. 
Większa liczba beneficjentów zakładów ubezpieczeń społecznych względem pomniejszającej się liczby pracowników odprowadzających składki wymusza reformy systemów emerytalnych. Zazwyczaj są one niechętnie przyjmowane przez społeczeństwo ${ }^{7}$. Dzieje się tak, gdyż z punktu widzenia poszczególnych jednostek każda wprowadzona w życie reforma oznacza zmianę umowy społecznej.

\section{Metodyka badań}

W pracy zastosowano krytyczną analizę literatury przedmiotu o tematyce adekwatności zabezpieczenia emerytalnego. Wykorzystano też podstawowe miary statystyczne, a także analizę korelacji między PKB per capita PPP a stopą zastąpienia. Autor dokonał również analizy porównawczej pomiędzy badanymi państwami. W celu zweryfikowania hipotezy zastosowano stopę zastąpienia jako miernik obrazujący proporcję między świadczeniami emerytalnymi a wynagrodzeniami.

Źródłem danych empirycznych, z których skorzystał autor, są bazy danych opublikowane przez instytucje międzynarodowe, takie jak World Bank i Eurostat. W celu uzupełnienia informacji posłużono się ponadto publikacjami urzędów statystycznych analizowanych państw ${ }^{8}$.

\section{Adekwatność systemów emerytalnych państw postradzieckich}

Adekwatność systemu emerytalnego to jeden z podstawowych stawianych przed nim celów. Wynika to z perspektywy mikroekonomicznej, zgodnie z którą systemy emerytalne traktowane są przez jednostki jako alokacja dochodu z okresu aktywności zawodowej na czas starości (Barr, 1993, 231; Góra, 2003, 19). Pracownicy

7 Przykładem niezadowolenia społeczeństwa mogą być strajki w Rosji, które towarzyszyły ostatniej reformie systemu emerytalnego w 2018 roku. Sprzeciw dotyczył całej reformy, a zwłaszcza podniesienia wieku emerytalnego kobiet do 63 lat (Artem'ev, 2018). W celu wyjaśnienia należy dodać, że najpierw planowano podnieść wiek emerytalny kobiet do 63 lat, ale po protestach prezydent Putin zmniejszył go do 60.

8 Odpowiednio dla Armenii, Azerbejdżanu, Białorusi, Estonii, Gruzji, Kirgistanu, Kazachstanu, Litwy, Łotwy, Mołdawii, Rosji, Tadżykistanu, Ukrainy i Uzbekistanu są to: Statistical Committee of the Republic of Armenia, The State Statistical Committee of the Republic of Azerbaijan, Nacional'nyj statističeskij komitet Respubliki Belarus', Statistikaamet, National Statistics Office of Georgia (GEOSTAT), Nacional'nyj statističeskij komitet Kyrgyzskoj Respubliki, Ministerstvo Nacional'noj Èkonomiki Respubliki Kazahstan Komitet po Statistike, Lietuvos Statistikos Departamentas, Centrālā statistikas pārvalde, National Bureau of Statistics of the Republic of Moldova, Federal'naâ služba gosudarstvennoj statistiki, Agency on statistics under president of The Republic of Tajikistan (TAJSTAT), Deržavnoï Službi Statistiki Ukraïni oraz Gosudarstvennyj komitet Respubliki Uzbekistan po statistike. 
odprowadzający składki na zabezpieczenie emerytalne spodziewają się, że przeznaczając część swojego dochodu na ten cel, w przyszłości otrzymają świadczenie, które pozwoli im na godziwe warunki życia. F. Chybalski $(2016,22)$ stwierdza, że „Adekwatność emerytur jest zazwyczaj kojarzona z hojnością systemów emerytalnych, niemniej współcześnie nie można tej oceny sprowadzać wyłącznie do poziomu świadczeń emerytalnych". Zauważa także, że nieefektywny i niestabilny finansowo system emerytalny nie może zapewnić adekwatnych świadczeń (Chybalski, 2016, 17).

Podstawowymi wymiarami adekwatności są wygładzenie konsumpcji zgodnie z modelem cyklu życia oraz eliminacja ryzyka ubóstwa. Takie podejście jest uznawane przez największe organizacje międzynarodowe, między innymi Komisję Europejską - KE (European Commission, 2003) oraz OECD (2013). Adekwatne emerytury to takie, które są w stanie realizować cele zarówno ekonomiczne, jak i społeczne (Bednarczyk, 2015, 42). Dodatkowym wymiarem, jaki wskazuje KE, jest solidarność nie tylko na poziomie wewnątrzpokoleniowym, ale i międzypokoleniowym. Natomiast Międzynarodowa Organizacja Pracy (MOP) jako dodatkowy cel przyjmuje zapobieganie dyskryminacji płciowej ze względu na wysokość otrzymywanej emerytury.

W Konwencji nr 102 MOP z 1952 roku ratyfikowano przepisy ${ }^{9}$, zgodnie z którymi adekwatność mierzona za pomocą stopy zastąpienia powinna wynosić minimum $40 \%$, aby otrzymywane świadczenie wystarczyło na pokrycie podstawowych potrzeb życiowych. K. Bielawska $(2016,32)$ stwierdza, że standard życia z okresu aktywności zawodowej pozwala utrzymać ten wskaźnik na poziomie $60-70 \%$. Podobnie wypowiada się A. Lel'čuk, który przyjmuje, że osoby starsze nie muszą otrzymywać emerytury na takim samym poziomie jak wynagrodzenie, ponieważ w okresie starości wydatki powinny być niższe niż w młodości. Uzasadnia to faktem, iż kredyty lub inne zobowiązania finansowe, które były zaciągane na zakup mieszkania/domu lub samochodu, zazwyczaj są już spłacone (bądź do końca okresu spłaty pozostało niewiele czasu). Do tego dzieci są dorosłe i niezależne, w związku z czym nie ma potrzeby ponoszenia nakładów na przykład na ich edukację. Zauważa również, że emeryci często mają wiele dodatkowych korzyści, które pozwalają im mniej wydawać, na przykład zniżki lub bezpłatne leki, rabaty w sklepach, a także tańsze/darmowe podróże komunikacją zbiorową (Lel'čuk, 2014, 3).

Zgodnie z podejściem zaproponowanym przez Chybalskiego $(2016,24)$ adekwatność powinno się rozpatrywać wielowymiarowo: ochrona przed ubóstwem, wygładzenie konsumpcji i zróżnicowanie adekwatności ze względu na płeć. Autor niniejszego artykułu postanowił skupić się wyłącznie na drugim aspekcie, gdyż odnosi się do okresu, w którym jednostka jest aktywna zawodowo, a także do kon-

\footnotetext{
9 Artykuły 25-30 dotyczące świadczeń na starość.
} 
sumpcji w czasie pobierania świadczenia emerytalnego. Pominięto zróżnicowanie ze względu na płeć, gdyż wiele urzędów statystycznych analizowanych państw nie rozróżnia w swoich opracowaniach wysokości emerytur uzyskiwanych przez kobiety i mężczyzn. W celu dokonania pomiaru i oceny autor artykułu postanowił wykorzystać jeden ze wskaźników używanych w analizach międzynarodowych stopę zastąpienia. Ważne jest także, iż traktuje się ją jako jeden z najbardziej istotnych wskaźników adekwatności w analizach jednowymiarowych.

Dokonując przeglądu literatury dotyczącej badań nad adekwatnością systemów emerytalnych, można zauważyć, że najczęściej stosowanym wskaźnikiem jest miara zastąpienia ${ }^{10}$. A. Biggs oraz G. Springstead zwracają uwagę, że wskaźnik ten może być problematyczny w porównaniach międzynarodowych. Jest to spowodowane tym, że metodyka badań może się różnić w zależności od przyjętego przez badacza podejścia. Mianownik zazwyczaj jest ten sam — przychody uzyskiwane w okresie aktywności zawodowej. Natomiast licznik jest rozumiany indywidualnie. Może być do niego wliczony cały dochód na emeryturze lub jego składowa, na przykład świadczenie z zakładu ubezpieczeń społecznych (Biggs, Springstead, 2008, 2). W związku z tym Biggs i Springstead proponują inne podejścia do oceny adekwatności systemów emerytalnych, którą uważają za miarę względną. Wśród ich propozycji można wyróżnić między innymi wykorzystanie średnich zarobków z całej aktywności zawodowej skorygowane o inflację (przed ubieganiem się o świadczenie socjalne).

Głównymi argumentami przemawiającymi za zastosowaniem stopy zastąpienia jako miary adekwatności jest prostota i intuicyjna konstrukcja tego wskaźnika. Interpretacja uzyskanej wartości jest dość jednoznaczna, a wyniki można bezpośrednio porównywać dla różnych systemów emerytalnych. W związku z tym autor artykułu zdecydował się określić stopy zastąpienia dla poszczególnych państw postradzieckich, a w dalszej kolejności dokonać analizy porównawczej.

Dokonując porównań średniej wielkości stopy zastąpienia w badanym okresie, można stwierdzić, że tylko pięć państw spełnia wymogi określone przez MOP. Są to Estonia, Litwa, Białoruś, Łotwa i Ukraina. Najwyższa średnia stopa zastąpienia występuje w Estonii (48,5\%), natomiast najniższa wartość tego wskaźnika jest w Gruzji (14,56\%) (zob. wykres 1). W wypadku krajów bałtyckich ${ }^{11}$ wynik ten może być zasługą polityki prowadzonej przez Unię Europejską (otwarta metoda koordynacji). Warto jednak zauważyć, że żaden kraj postradziecki nie ma średniej stopy zastąpienia wyższej niż średnia dla państw członkowskich UE. Interesującym przypadkiem jest tu Białoruś, która jest uważana za jedno z biedniejszych państw europejskich ${ }^{12}$ (wśród analizowanych państw jest na 6. miejscu co do

10 Takie badania zostały przeprowadzone między innymi przez Biggs i Springstead (2008) oraz Holzmann i Guven (2009).

11 Są to: Estonia, Litwa i Łotwa.

12 PKB per capita PPP w 2017 roku wynosiło 18 847,9 dolara (World Bank, 2018). 
wielkości PKB per capita PPP w dolarach w 2017 roku). Średnia stopa zastąpienia plasuje jednak ten kraj na 3. miejscu pod względem stosunku średniej emerytury do przeciętnego miesięcznego wynagrodzenia.

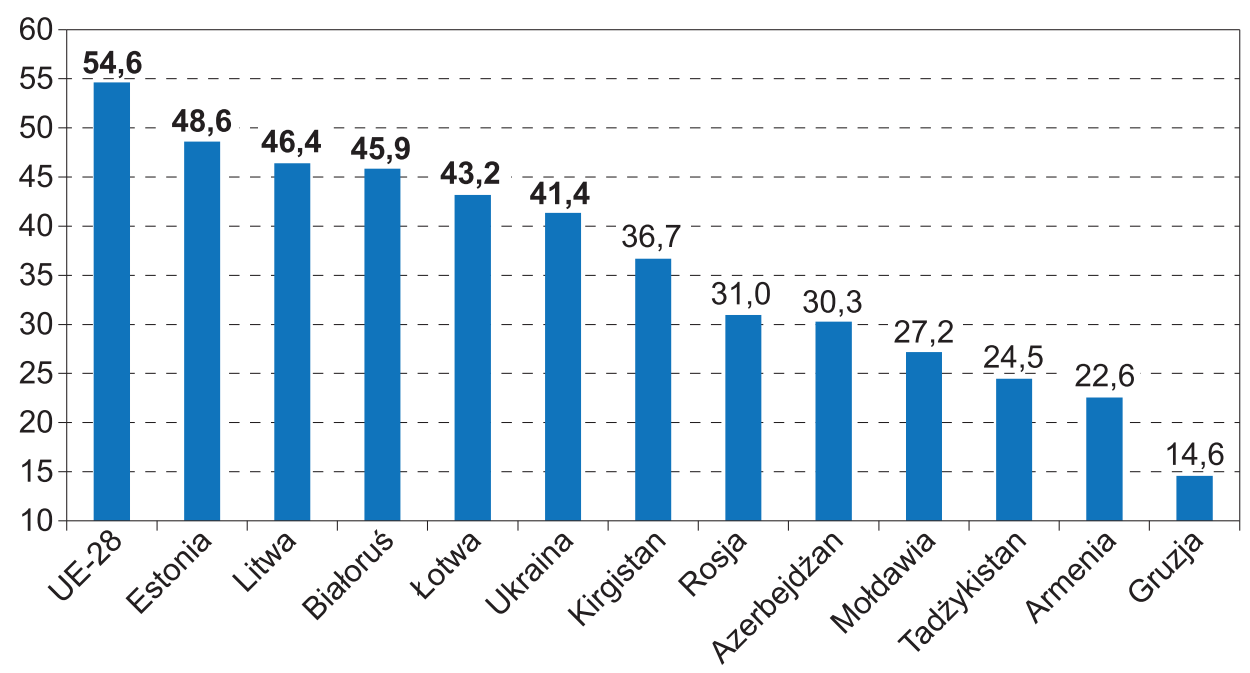

Wykres 1. Średnia wysokość stopy zastąpienia w latach 2005-2017 (w \%)

Uwaga: do 2009 roku zastosowano wskaźnik dla UE-27 (przed akcesją Chorwacji), od 2010 roku użyto wskaźnika dla UE-28

Źródło: opracowanie własne na podstawie danych urzędów statystycznych poszczególnych państw i Eurostat.

Dokonując analizy danych dla poszczególnych lat, można zauważyć zmiany, jakie następowały przez 12 lat. W wypadku siedmiu państw odnotowano wzrost tego wskaźnika, a w pięciu spadek (zob. tabela 2). Największa poprawa nastąpiła w Azerbejdżanie (prawie 17 p.p.), a pogorszenie — wynoszące 18 p.p. — w latach 2005-2017 zauważono na Łotwie. To właśnie tam na początku analizowanego okresu, to jest w 2005 roku, występował najwyższy wskaźnik - 61\%. Najmniejszy był z kolei w Armenii - mniej niż 20\%. Na koniec okresu badawczego, to jest w 2017 roku, najlepszą adekwatnością analizowaną za pomocą stopy zastąpienia cechowała się Białoruś (46,2\%). Także wtedy stosunek emerytury do wynagrodzenia najgorzej kształtował się w Armenii. Gdyby jednak wziąć pod uwagę sytuację rok wcześniej, należałoby zwrócić uwagę na Gruzję, w której wskaźnik ten nie przekroczył nawet $17 \%$.

Jeżeli za punkt odniesienia weźmie się natomiast wartość określoną przez MOP, czyli stopę zastąpienia na poziomie minimum $40 \%$, możemy stwierdzić, że zaledwie trzy państwa przez cały analizowany okres utrzymały ten wskaźnik na zalecanym poziomie. Są to: Białoruś, Estonia i Litwa. W wypadku trzech innych krajów oscyluje on w okolicach tej umownej wartości — Łotwa, Ukraina i Kirgistan. 
Jak już wspomniano, na początku analizowanego okresu Łotwa charakteryzowała się najwyższym wskaźnikiem, ponad 60\%, aby w 2008 roku zmniejszył się on o przeszło połowę - do wartości 30\% (najniższa wartość dla tego kraju). Następnie wzrastał on do 53\% w 2011 roku i znów zaczął spadać aż do 2015 roku.

Kolejnym państwem, które stara się utrzymywać poziom zalecany przez MOP, jest Ukraina. W latach 2008-2014 udało jej się osiągnąć wartość stopy zastąpienia powyżej 40\%, jednakże od 2015 roku widać spadek tego wskaźnika.

Należy zwrócić również uwagę na jedno z państw azjatyckich, mianowicie Kirgistan. To jedyny kraj z tego obszaru geograficznego, któremu udało się przekroczyć tę ,granicę”. Nastąpiło to w latach 2010 i 2011. Od roku 2012 widać jednak spadek wartości wskaźnika, aczkolwiek można przypuszczać, że wyhamowanie spadku w 2017 roku będzie oznaczać polepszenie się sytuacji osób starszych w Kirgistanie w kolejnych latach.

Tabela 2. Stopa zastąpienia w państwach postradzieckich w latach 2005-2017 (w \%)

\begin{tabular}{|l|c|c|c|c|c|c|c|c|c|c|c|c|c|}
\cline { 2 - 10 } & 2005 & 2006 & 2007 & 2008 & 2009 & 2010 & 2011 & 2012 & 2013 & 2014 & 2015 & 2016 & 2017 \\
\hline Armenia & 18,8 & 17,5 & 17,2 & 24,5 & 25,5 & 26,4 & 25,0 & 26,2 & 19,9 & 22,6 & 23,6 & 23,2 & 22,9 \\
\hline Azerbejdżan & 19,4 & 19,1 & 19,1 & 22,9 & 32,2 & 30,3 & 31,0 & 36,4 & 35,8 & 38,4 & 37,1 & 35,5 & 36,4 \\
\hline Białoruś & 45,0 & 47,0 & 46,9 & 44,0 & 43,0 & 47,3 & 48,8 & 50,4 & 47,1 & 43,4 & 41,8 & 45,3 & 46,2 \\
\hline Estonia & 47,0 & 49,0 & 47,0 & 45,0 & 52,0 & 55,0 & 54,0 & 50,0 & 50,0 & 47,0 & 43,0 & 45,0 & 45,0 \\
\hline Gruzja & b.d. & b.d. & 11,2 & 11,8 & 13,4 & 13,9 & 13,7 & 13,5 & 16,1 & 18,5 & 16,6 & 16,9 & b.d. \\
\hline Kirgistan & b.d. & b.d. & b.d. & 27,1 & 34,6 & 40,1 & 40,1 & 39,8 & 39,7 & 37,9 & 36,9 & 35,3 & 35,3 \\
\hline Litwa & 47,0 & 44,0 & 40,0 & 43,0 & 48,0 & 58,0 & 52,0 & 45,0 & 48,0 & 45,0 & 46,0 & 45,0 & 43,0 \\
\hline Lotwa & 61,0 & 49,0 & 38,0 & 30,0 & 34,0 & 47,0 & 53,0 & 49,0 & 47,0 & 44,0 & 42,0 & 42,0 & 43,0 \\
\hline Mołdawia & b.d. & b.d. & b.d. & 26,3 & 29,2 & 28,2 & 28,2 & 28,4 & 27,9 & 26,7 & 25,9 & 25,6 & 25,6 \\
\hline Rosja & 27,6 & 25,6 & 22,9 & 24,3 & 27,9 & 35,7 & 35,1 & 34,0 & 33,3 & 33,2 & 35,2 & 33,8 & 34,0 \\
\hline Tadżykistan & 19,0 & 22,6 & 25,5 & 20,3 & 28,7 & 25,0 & 27,0 & 27,0 & 25,2 & 26,7 & 25,2 & 23,1 & 23,2 \\
\hline Ukraina & 39,2 & 39,1 & 35,4 & 43,0 & 49,0 & 46,1 & 43,7 & 41,4 & 45,0 & 43,9 & 37,7 & 32,8 & b.d. \\
\hline
\end{tabular}

Źródło: opracowanie własne na podstawie danych urzędów statystycznych poszczególnych państw.

T. Jedynak $(2017,130)$ zwraca uwagę, że należy również dokonywać porównania stopy zastąpienia w danym państwie z oczekiwaną stopą zwrotu (ang. targeted replacement rate) przez poszczególne jednostki. Dopiero jeżeli wartość rzeczywista przekracza wartość docelową, można uznać, że analizowany system emerytalny jest adekwatny. W wypadku występowania różnicy należy mówić o luce eme- 
rytalnej ${ }^{13}$. Większość opracowań wskazuje, iż docelowa stopa zastąpienia powinna mieścić się w przedziale 60-80\% (World Bank, 1994; OECD, 2015; An ideal retirement system, 2016), aczkolwiek E. Whitehouse (2014) w swojej pracy podnosi, że odpowiedni poziom mieści się już w przedziale $50-60 \%$.

Dokonując analizy adekwatności w taki sposób, dojdziemy do wniosku, że obecnie żaden kraj postradziecki nie ma adekwatnego systemu emerytalnego przy porównaniu oczekiwanej stopy zastąpienia z rzeczywistą. Warunek ten spełniała jedynie Łotwa w 2005 roku. Natomiast jeżeli przyjmie się propozycję Whitehouse'a, można uznać za adekwatne systemy emerytalne Estonii (w latach 2009-2013), Litwy (2010-2012), a także wspomnianą już Łotwę w 2011 roku oraz Białoruś w 2012 roku. W ostatnim analizowanym roku, to jest w 2017, najbliżej tego wskaźnika były państwa bałtyckie oraz Białoruś. Z kolei wśród państw azjatyckich najbliżej tych wartości znalazły się Afganistan i Kirgistan — do minimalnej wartości wskazywanej przez Whitehouse'a brakuje im jednak około 15 p.p.

Stopa zastąpienia, która obrazuje stosunek emerytur do wynagrodzeń, powinna zwiększać się na poziomie zbliżonym do tempa rozwoju gospodarczego mierzonego za pomocą PKB per capita PPP. Założenie to opiera się na tym, że transfery socjalne otrzymywane z zakładów ubezpieczeń społecznych są w różny sposób waloryzowane. Dzieje się tak, aby zapewnić osobom starszym środki na utrzymanie zbliżonego poziomu życia mimo inflacji, a także wzrostu wynagrodzeń w gospodarce.

W związku z tym autor postanowił dokonać analizy korelacji. Korelacja istotna statystycznie między PKB per capita PPP danego państwa a stopą zastąpienia w latach 2005-2017 występuje tylko dla czterech analizowanych krajów. Są to: Azerbejdżan (,907**), Gruzja (,895**), Rosja (,752**) i Mołdawia (-,761*). Zaprezentowane wyniki oznaczają, że wzrost PKB per capita w Azerbejdżanie, Gruzji i Rosji przekłada się na wzrost stopy zastąpienia, czyli można przypuszczać, że polepsza się sytuacja osób starszych. Niestety w wypadku Mołdawii sytuacja wygląda najgorzej — zwiększenie się produktu krajowego brutto przekłada się na pogorszenie stopy zastąpienia. W przypadku innych państw korelacja nie była istotna statystycznie. W celu ukazania relacji występującej pomiędzy tymi wskaźnikami, to jest stopą zastąpienia a PKB per capita PPP, autor postanowił stworzyć wykres rozrzutu. Jest on graficzną interpretacją korelacji za pomocą tak zwanej chmury rozrzutu (zob. wykres 2).

13 Jest to rzeczywiste świadczenie niższe od pożądanego przez jednostki. 


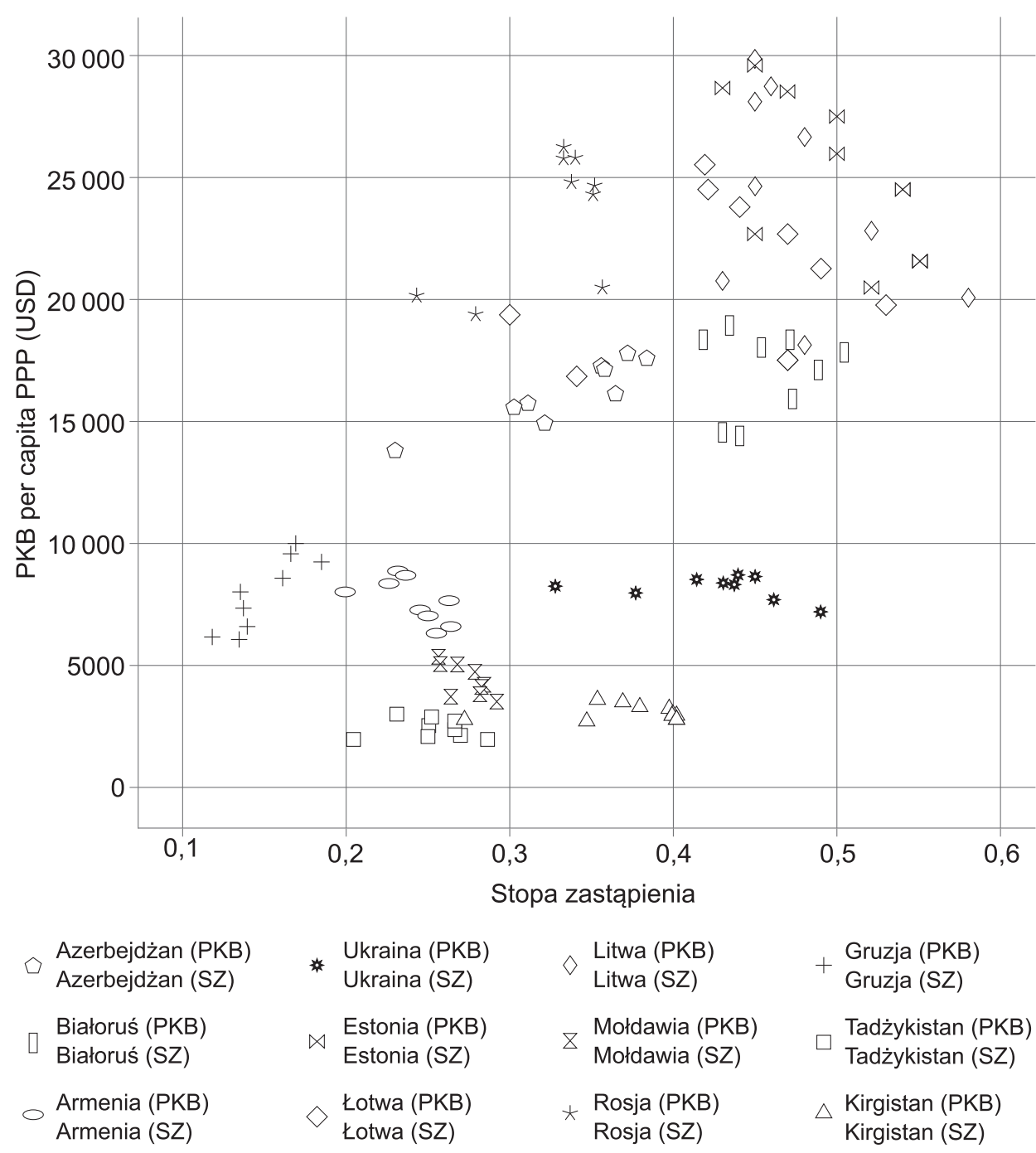

Wykres 2. Rozrzut punktów dla PKB per capita PPP i stopy zastąpienia dla danych przekrojowo-czasowych z lat 2005-2017

Źródło: opracowanie własne na podstawie World Bank (2018) i udanych rzędów statystycznych poszczególnych państw.

\section{Wnioski}

Analizując państwa postradzieckie w latach 2005-2017, można stwierdzić, że w żadnym z nich nie występuje adekwatny system emerytalny, zapewniający transfery w wysokości 60\% wynagrodzenia. Jedynym wyjątkiem była Łotwa 
w 2005 roku, kiedy to stopa zastąpienia wynosiła 61\%. Warto jednak zauważyć, że istnieją kraje, które spełniają wymagania Konwencji nr 102 MOP. Są to: Białoruś, Estonia, Litwa i Łotwa. Reszta państw postradzieckich nie zapewnia nawet tego minimalnego poziomu bezpieczeństwa socjalnego zamieszkującym je osobom starszym.

Potwierdza się zatem hipoteza, jaką autor przyjął przy pisaniu niniejszej pracy — państwa europejskie cechują się wyższymi poziomami adekwatności systemów emerytalnych w porównaniu do krajów azjatyckich. W związku z tym rządzący wszystkich państw postradzieckich, a szczególnie tych z obszaru azjatyckiego, powinni dokonać reform systemów emerytalnych. Poprawę wskaźników systemów emerytalnych, między innymi adekwatności, z tej grupy krajów powinni przede wszystkim rozważyć decydenci Gruzji, Armenii, Tadżykistanu oraz Mołdawii.

Podniesienia wartości wskaźników można dokonać na kilku płaszczyznach. Jedną z możliwości jest wyrównanie wieku emerytalnego dla obu płci, podobnie jak ma to miejsce w wielu państwach członkowskich UE. Działanie to pozwala zmniejszyć problem dyskryminacji występujący w systemach emerytalnych, a także podwyższyć świadczenia otrzymywane przez kobiety. Przełoży się to na poprawę adekwatności emerytur, a także poprawi stabilność systemów emerytalnych. Inną propozycją na poprawę wskaźników dotyczących systemów emerytalnych może być podniesienie wieku emerytalnego, jak ma to już miejsce na przykład w Rosji i na Białorusi. Do pozostałych możliwości można zaliczyć chociażby wzrost składek na zabezpieczenie społeczne. Jednakże, jak już zostało wspomniane, wszelkie reformy emerytalne powodują niepokoje społeczne, gdyż zmieniane są warunki umowy społecznej. W związku z tym działania te należy poprzedzić konsultacjami zarówno społecznymi, jak i z ekspertami. Należy także pamiętać, że efekty będą widoczne dopiero za kilkadziesiąt lat, tak więc reformy powinny być przeprowadzane stopniowo i być rozciągnięte $\mathrm{w}$ czasie, aby była możliwość dostosowania się społeczeństwa.

\section{Bibliografia}

Agency on statistics under president of The Republic of Tajikistan (TAJSTAT) (2018). Data dostępu: 20.11.2019, https://www.stat.tj/en/.

Artem'ev, M. (25.10. 2018). Nezamečennye mitingi. Kčemu privedet nedovol'stvo pensionnoj reformoj. Data dostępu: 20.11.2019, http://www.forbes.ru/biznes/364153-nezamechennye-mitingik-chemu-privedet-nedovolstvo-pensionnoy-reformoy.

Barr, N. (1993). Ekonomika polityki społecznej. Poznań: Wydawnictwo Akademii Ekonomicznej w Poznaniu.

Bednarczyk, T. (2015). Wyzwania demograficzne dla systemów emerytalnych w Unii Europejskiej. Annales Universitatis Mariae Curie-Skłodowska. Sectio H, 49(2), 33-50.

Bielawska, K. (2016). Adekwatność emerytur w świetle zmian polskiego systemu emerytalnego. Zarzadzanie i Finanse. Journal of Management and Finance, 14(4), 31-44. 
Biggs, A.G., Springstead, G. (1.11.2008). Alternate measures of replacement rates for social security benefits and retirement income. Social Security Bulletin, 68(2), 1-19. Data dostępu: 15.11.2019, https://papers.ssrn.com/sol3/papers.cfm?abstract id=1299029.

Centrālā statistikas pārvalde (2018). Data dostępu: 20.11.2019, https://www.csb.gov.lv/en.

Chybalski, F. (2016). Adekwatność dochodowa, efektywność i redystrybucja w systemach emerytalnych. Ujęcie teoretyczne, metodyczne i empiryczne. Warszawa: Wydawnictwo C.H. Beck.

Deržavnoï Službi Statistiki Ukraïni (2018). Data dostępu: 20.11.2019, http://www.ukrstat.gov.ua.

European Commision (2003). Adequateand Sustainable Pensions. Luksembourg: Publication Office.

European Commission (2018). Your rights country by country. Data dostępu: 20.11.2019, https:// ec.europa.eu/social/main.jsp?catId=858\&langId=en.

Eurostat (2018). Data dostępu: 20.11.2019, https://ec.europa.eu/eurostat/web/main/home.

Federal'naâ služba gosudarstvennoj statistiki (2018). Data dostępu: 20.11.2019, http://www.gks.ru.

Federal'nyj zakon "O vnesenii izmenenij v otdel'nye zakonodatel'nye akty Rossijskoj Federacii po voprosam naznačeniâ i vyplaty pensij" ot 3.10.2018, N 350-FZ. Data dostępu: 15.11.2019, http://www.consultant.ru/cons/cgi/online.cgi?req=doc\&base=LAW\&n=308156\&fld=134\&d$\mathrm{st}=1000000001,0 \& \mathrm{rnd}=0.42717948098688674 \# 07653142668128157$.

Gosudarstvennyj komitet Respubliki Uzbekistan po statistike (2018). Data dostępu: 20.11.2019, https://stat.uz/ru/.

Góra, M. (2003). System emerytalny. Warszawa: PWE.

Holzmann, R., Guven, U. (2009). Adequacy of Retirement Income after Pension Reform in Central, Eastern, and Sothern Europe: Eight Country Studies. Washington: The World Bank.

An ideal retirement system (2016). Mercer. Data dostępu: 3.11.2018, https://www.mercer.com.au/ insights/focus/CFA-mercer-ideal-retirement-system.html.

Jedynak, T. (2017). Luka emerytalna a potencjał do oszczędzania w polskich gospodarstwach domowych. Zeszyty Naukowe Politechniki Poznańskiej. Organizacja i Zarządzanie, 73, 127143. DOI: 10.21008/j.0239-9415.2017.073.09.

Jurek, Ł. (2012). Ekonomia starzejacego się społeczeństwa. Warszawa: Difin SA.

Lel'čuk, A. (14.04.2014). Uroven' pensionnogo obespečeniâ. Data dostępu: 15.11.2018, http://pensionreform.ru/files/69710/А.Лельчук.\%20Коэффициент\%20замещения.pdf.

Lietuvos Statistikos Departamentas (2018). Data dostępu: 20.11.2019, https://www.stat.gov.lt/home.

Maleva, T., Sinâvskaâ, O. (14.07.2011). Povyšenie pensionnogo vozrasta: pro et contra. Data dostępu: 15.11.2018, http://2020strategy.ru/data/2011/07/14/1214719869/4.pdf.

Międzynarodowa Organizacja Pracy (1952). Konwencja nr 102 Międzynarodowej Organizacji Pracy dotyczaca minimalnych norm zabezpieczenia społecznego. Genewa.

Ministerstvo Nacional'noj Ėkonomiki Respubliki Kazahstan Komitet po Statistike (2018). Data dostępu: 15.11.2018, http://economy.gov.kz/ru/kategorii/komitet-po-statistike?theme_version =special.

Nacional'nyj statističeskij komitet Kyrgyzskoj Respubliki (2018). Data dostępu: 15.11.2019, http:// www.stat.kg/ru/.

Nacional'nyj statističeskij komitet Respubliki Belarus' (2018). Data dostępu: 15.11.2019, http:// www.belstat.gov.by.

National Bureau of Statistics of the Republic of Moldova (2018). Data dostępu: 15.11.2019, http:// www.statistica.md/index.php?l=ru.

National Statistics Office of Georgia (GEOSTAT) (2018). Data dostępu: 15.11.2019, http://www. geostat.ge/index.php?action=0\&lang=eng.

OECD (26.11.2013). Pensions at a Glance 2013: OECD and G20 Indicators. Paris: OECD Publishing. Data dostępu: 31.10.2018, http://dx.doi.org/10.1787/pension_glance-2013-en.

OECD (1.12.2015). Pensions at a Glance 2015: OECD and G20 Indicators. Paris: OECD Publishing. Data dostępu: 31.10 .2018 , http://dx.doi.org/10.1787/pension_glance-2015-en.

Ekonomia — Wroclaw Economic Review 25/4 (2019)

(C) for this edition by CNS 
Okólski, M. (1997). Demograficzno-instytucjonalne antymonie współczesności. W W. Bielicki, J. Reykowski (red.), Dylematy wspótczesnej cywilizacji a natura człowieka (25-60). Poznań: Zysk i S-ka.

Pleśniak, A. (2014). Konsekwencje przemian demograficznych w świetle adekwatności i stabilności systemów emerytalnych. Studia Ekonomiczne Uniwersytetu Ekonomicznego w Katowicach, 167, 43-53. Data dostępu: 25.10.2018, https://www.sbc.org.pl/dlibra/publication/96655/edition/91164/content?ref=desc.

The State Statistical Committee of the Republic of Azerbaijan (2018). Data dostępu: 15.11.2019, https://www.stat.gov.az/?lang=en.

Statistical Committee of the Republic of Armenia (2018). Data dostępu: 15.11.2019, https://www. armstat.am/am/.

Statistikaamet (2018). Data dostępu: 15.11.2019, https://www.stat.ee/en.

Szumicz, T. (2004). Zabezpiecznie emerytalne w systemach zabezpieczenia społecznego. W T. Szumlicz, M. Żukowski (red.). Systemy emerytalne w krajach Unii Europejskiej (9-28). Warszawa: Twigger S.A.

Szumlicz, T. (2006). Ubezpieczenia społeczne: Teoria dla praktyki. Bydgoszcz: Oficyna Wydawnicza Branta.

Whitehouse, E. (2014). Earnings Related Schemes: Design, Options and Experience. World Bank Core Course. Data dostępu: 5.11.2018, https://olc.worldbank.org/sites/default/files/Whitehouse_Earnings\%20Related\%20Schemes_PCC15.pdf.

World Bank (1994). Averting the Age Crisis: Policies to Protect the Old and Promote Growth. Washington DC: World Bank.

World Bank Open Data (2018). Data dostępu: 15.11.2019, https://data.worldbank.org.

Związek Socjalistycznych Republik Radzieckich (28.11.2018). W Encyklopedia PWN. Data dostępu: 20.11.2019, http://encyklopedia.pwn.pl/haslo/Zwiazek-Socjalistycznych-Republik-Radzieckich;4002438.html. 